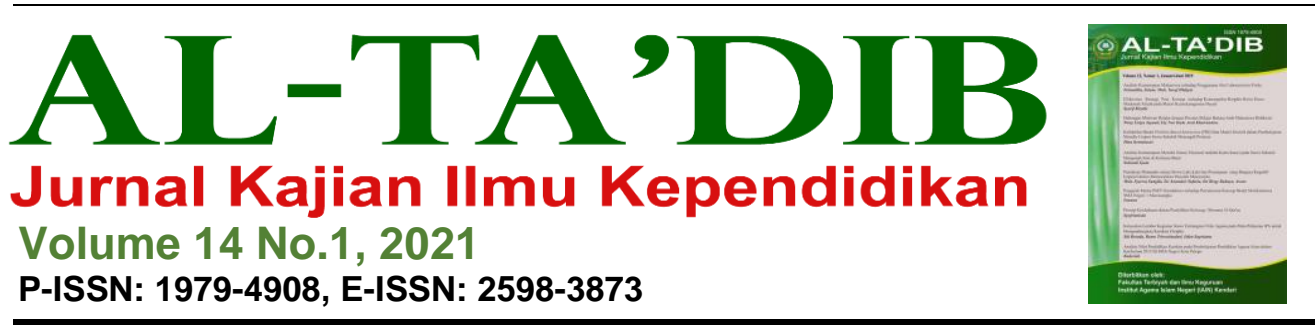

\title{
Penerapan Metode Kunci ABC (Aneka Berhitung Cepat): Pembelajaran Konsep Operasi Perkalian Matematika pada Siswa Sekolah Dasar
}

\author{
Sri Erdawati ${ }^{1}$, Arivaie Rahman ${ }^{2}$ \\ ${ }^{1}$ Sekolah Tinggi Agama Islam (STAI) Auliaurrasyidin Tembilahan, E-mail: sri.erdawati@stai-tbh.ac.id \\ ${ }^{2}$ Universitas Islam Indragiri (UNISI) Tembilahan, E-mail: arivai.rahman@yahoo.com
}

\begin{tabular}{l} 
ARTICLE INFO \\
\hline Keywords: \\
ABC key method; \\
elementary school; \\
mathematics \\
How to cite: \\
Erdawati, S., \& Rahman, \\
B. (2021). Penerapan \\
metode kunci ABC (Aneka \\
Berhitung Cepat): \\
Pembelajaran konsep \\
operasi perkalian \\
matematika pada siswa \\
sekolah dasar. Al-Ta'dib: \\
Jurnal Kajian Ilmu \\
Kependidikan, $14(1), 14-$ \\
30.
\end{tabular}

\begin{abstract}
This article reports the result of a classroom action research focusing on elementary school students' development in multiplication under Aneka Berhitung Cepat $(A B C)$ key method. Data were gathered from 19 students by means of tests, observations, documentation, and reflection within two cycles under planning, action, observation, and reflection stages. The result of qualitative analysis showed an increase in students' participation in learning activities and students' learning outcomes. This study implies that $A B C$ key method could be of consideration for math teachers to apply in the classroom.
\end{abstract}


INFORMASI ARTIKEL

Kata Kunci:

Matematika; metode kunci

$\mathrm{ABC}$; sekolah dasar

Cara Mensitasi:

Erdawati, S., \& Rahman,

B. (2021). Penerapan

metode kunci ABC (Aneka

Berhitung Cepat):

Pembelajaran konsep

operasi perkalian

matematika pada siswa

sekolah dasar. Al-Ta'dib:

Jurnal Kajian Ilmu

Kependidikan, 14(1), 14-

30.

\begin{abstract}
ABSTRAK
Artikel ini melaporkan hasil penelitian tindakan kelas yang berfokus pada perkembangan kemampuan perkalian siswa sekolah dasar menggunakan metode kunci Aneka Berhitung Cepat (ABC). Data dikumpulkan dari 19 siswa menggunakan tes, observasi, dokumentasi, dan refleksi dalam dua siklus meliputi tahapan perencanaan, tindakan, pengamatan, dan refleksi. Hasi analisis kualitatif menunjukkan adanya peningkatan dalam tingkat partisipasi siswa dalam kegiatan pembelajaran dan hasil belajar siswa. Penelitian ini mengindikasikan bahwa metode kunci ABC patut dipertimbangkan untuk diterapkan di kelas oleh guru matematika.
\end{abstract}

\section{Pendahuluan}

Penelitian mental aritmatika telah menjadi perhatian para peneliti dan guru peneliti dalam dekade terakhir (Olsen, 2015; Rizal, 2011; Stott, Hewana, Koliti, \& Mase, 2013). Fleksibilitas mental dalam pembelajaran matematika berbasis permainan bersifat menantang karena adanya aturan yang berlaku yang memiliki tujuan pengembangan kognitif matematika yang jelas (Stott, dkk., 2013). Mental aritmatika sendiri memainkan peran yang sangat penting dalam kurikulum sehingga beragam metode diterapkan dalam aktivitas pembelajaran yang bersifat menyenangkan (Olsen, 2015). Aktivitas yang menyenangkan tersebut diharapkan dapat membangkitkan motivasi belajar serta membangun sikap belajar positif dan partisipasi belajar aktif peserta didik saat mereka dilibatkan dalam pembelajaran dalam berbagai tingkatan kognitif (La Hadi \& Dedyerianto, 2020; Verschaffel, Luwel, Torbeyns, \& Van Dooren, 2009).

Salah satu metode mental aritmatika adalah metode kunci ABC (Aneka Berhitung Cepat) dalam pembelajaran matematika. Metode kunci ABC ini ditemukan pertama kali oleh Hendra sekitar tahun 1953. Ketika itu materinya masih terbatas pada bilangan 6-10. Kendati demikian, metode kunci ABC terus berkembang dengan nama metode JHC Hand-Sis (Hensis) (Hendra \& Widiastuti, 2013). Metode ini diterapkan secara terbatas hanya di Indonesia dan belum diterapkan dalam skala global. Secara khusus, metode ABC ini tidak memiliki kesamaan yang signifikan dengan metode lainnya, namun secara umum masuk dalam kategori berhitung cepat atau mental aritmatika. 
Beberapa penelitian terkait penerapan metode mental aritmatika menggunakan jari telah dilakukan (Caffriyati \& Lisa, 2015; Ekasanti; 2017; Sari, 2011; Surat, 2017). Penelitian relevan dilakukan oleh Sari (2011) di sebuah sekolah dasar dengan menerapkan metode kunci ABC pada pembahasan perkalian matematika kepada 28 orang siswa kelas III. Hasil penelitiannya menunjukkan bahwa jika metode ABC dilaksanakan sesuai dengan prodesur maka akan mampu meningkatkan hasil belajar siswa (Sari, 2011). Selain itu, penelitian mental aritmatika juga telah dilakukan oleh Caffriyati dan Lisa (2015) yang fokus pada penerapan metode Kalkulator Jari Tangan dalam meningkatkan pemahaman operasi perkalian pada materi keliling, luas persegi, dan persegi panjang pada siswa sekolah dasar. Hasil penelitian tindakan kelas mereka menunjukkan bahwa ada peningkatan yang signifikan pada siklus satu dan dua, sehingga mereka menyimpulkan bahwa metode ini dapat diterapkan untuk meningkatkan pemahaman siswa sekolah dasar terhadap perkalian pada materi keliling, luas persegi, dan persegi panjang (Caffriyati \& Lisa, 2015).

Penelitian lain terkait mental aritmatika metode jari juga telah dilakukan oleh Ekasanti (2017). Ia meneliti tentang penerapan metode Jaritmatika pada anak tunagrahita ringan. Hasil penelitiannya menunjukkan bahwa metode Jaritmatika sangat efektif diterapkan dan dapat meningkatkan kemampuan berhitung perkalian bagi anak tunagrahita utamanya ketika mereka menghitung perkalian bilangan 6-10 dan hasil devisiasi (Ekasanti, 2017). Selain itu, Surat (2017) juga melakukan penelitian serupa dengan fokus pada metode Kejar yang diterapkan pada anak sekolah dasar. Metode Kejar dianggap sangat efektif sebab dapat dipraktikkan secara ekonomis tanpa alat tertentu, melainkan dengan jari jemari yang terintegral dengan diri siswa (Surat, 2017).

Dari beberapa penelitian terkait penerapan metode dalam pembelajaran mental aritmatika di atas, masih sangat jarang yang mengeksplorasi penerapan metode kunci ABC (lihat Sari, 2011). Sementara itu, beberapa penelitian lainnya lebih kepada mengeksplorasi cara menghitung cepat dengan metode yang berbeda, yakni metode Kalkulator Jari Tangan, metode Jaritmatika, dan metode Kejar (lihat Caffriyati \& Lisa, 2015; Ekasanti; 2017; Surat, 2017). Untuk mengisi celah dalam penelitian dengan fokus penerapan metode $\mathrm{ABC}$ dalam pembelajaran matematika di tingkat sekolah dasar, penelitian ini dilakukan guna mengeksplorasi apakah metode kunci ABC dapat meningkatkan partisipasi aktif siswa dan mengembangkan hasil belajar perkalian matematika mereka. Hasil penelitian ini diharapkan dapat menjadi informasi tambahan bagi pihak terkait seperti sekolah dan guru matematika dalam mengintegrasikan metode pembelajaran yang mennyenangkan bagi siswa sehingga potensi dan prestasi hasil belajar mereka menjadi lebih maksimal. 


\section{Metode Penelitian}

Penelitian ini termasuk dalam jenis penelitian tindakan kelas (PTK) atau classroom action research (CAR). Penelitian tindakan kelas (PTK) merupakan pencermatan dalam bentuk tindakan terhadap kegiatan belajar yang sengaja dimunculkan dan terjadi dalam sebuah kelas secara bersamaan. Tindakan tersebut diberikan oleh guru atau dengan arahan guru yang kemudian dilakukan oleh siswa (Suryadi, 2012).

Penelitian ini dilakukan di kelas IV di salah satu sekolah dasar negeri di Provinsi Riau, Indonesia. Peneliti menggunakan pendekatan PTK dalam penelitian ini dengan beberapa pertimbangan. Sebelum metode kunci ABC diterapkan pada siswa kelas IV di sekolah dasar negeri ini, peneliti telah melakukan pengamatan awal dan melihat fenomena bahwa siswa di kelas tersebut masih relatif mengalami kesulitan dalam mengoperasikan sistem perkalian. Dalam hal metode pengajaran, siswa di kelas tersebut masih dibekali dengan metode menghafal perkalian 1 x 1 sampai 9 × 9. Untuk menyelesaikan soal perkalian 2 digit, guru cenderung memberikan solusi cara perkalian bersusun ke bawah dengan hasil 3 digit atau lebih. Hasil pengamatan awal terhadap metode mengajar guru tersebut menunjukkan bahwa guru belum menerapkan metode alternatif yang lebih variatif, sehingga berdampak pada partisipasi aktif siswa di dalam kelas yang masih terlihat minim.

Selain itu, hasil pengamatan awal menunjukkan bahwa kemampuan siswa di dalam kelas tidak sama. Saat pemberian materi di mata pelajaran matematika, sebagian siswa telah paham, sedangkan sebagian yang lain belum mengerti sama sekali. Secara formatif, kondisi penyerapan materi tergambar pada hasil evaluasi yang menunjukkan sebagian besar siswa di kelas tersebut belum mampu menyelesaikan hitungan perkalian dengan tepat dan benar. Kemampuan siswa di kelas tersebut tergambar pada hasil belajar yang belum mencapai standar KKM 65 dan ketuntasan klasikal 75\%. Data awal yang diperoleh dari guru mata pelajaran matematika di kelas tersebut menunjukkan angka nilai rata-rata ulangan harian I siswa adalah 52,4, sedangkan nilai rata-rata ulangan harian II adalah 59,5. Kedua nilai rata-rata nilai ulangan tersebut masih rendah dari apa yang diharapkan, sehingga dibutuhkan intervensi metode pengajaran alternatif yang bersifat menyenangkan seperti metode mental aritmatika, dalam hal ini metode kunci ABC.

Penelitian ini melibatkan 19 orang siswa yang terdiri atas 10 siswa laki-laki dan 9 orang siswa perempuan. Kesembilanbelas orang siswa ini merupakan jumlah keseluruhan siswa kelas IV di sekolah tempat penelitian ini dilakukan. Peneliti telah memperoleh izin dari masing-masing orang tua siswa ini untuk menjadikan siswa sebagai partisipan penelitian. Peneliti telah 
menjelaskan bahwa akan menerapkan metode kunci ABC yang dapat digunakan untuk menyelesaikan operasi perkalian matematika pada siswa. Ketika metode ini diterapkan, respon siswa sangat positif, sebab metode ini mudah dipraktekkan. Tetapi, metode ini bukan untuk melihat respon siswa, melainkan untuk melihat hasil belajar siswa pada materi perkalian.

Model penelitian yang diterapkan dalam PTK ini mengadopsi model yang dikembangkan oleh Kemmis dan McTaggart. Metode yang diterapkan dalam penelitian ini dilaksanakan melalui dua siklus dan masing-masing siklus terdiri atas tiga kali pertemuan. Masing-masing siklus telah melalui empat tahapan penting, sebagaimana diuraikan dalam Tabel 1.

Tabel 1. Empat Tahapan Siklus PTK

\begin{tabular}{|c|c|c|}
\hline No & Tahapan & Kegiatan dalam PTK \\
\hline 1 & Perencanaan (planning) & $\begin{array}{ll}\text { a. } & \text { Melakukan analisis SK/KD } \\
\text { b. } & \text { Memilih satu pokok bahasan } \\
\text { c. } & \text { Membuat RPP } \\
\text { d. } & \text { Membuat LKS } \\
\text { e. } & \text { Menyiapkan sarana pendukung kegiatan } \\
& \text { pembelajaaran } \\
\text { f. } & \text { Mempersiapkan instrumen dan menganalisis data } \\
& \text { proses serta hasil tindakan } \\
\text { g. } & \text { Menyusun alat evaluasi }\end{array}$ \\
\hline 2 & Pelaksanaan (action) & $\begin{array}{ll}\text { a. } & \text { Apersepsi } \\
\text { b. } & \text { Memperkenalkan dan menjelaskan langkah } \\
\text { c. } & \text { Metode Kunci ABC } \\
\text { d. } & \text { Membelaskan materi perkalian soal perkalian kepada siswa } \\
\text { e. } & \text { Menjelaskan cara pengengerjaan soal perkalian } \\
& \text { kepada siswa } \\
\text { f. } & \text { Membimbing siswa mengerjakan soal perkalian } \\
\text { g. } & \text { Meminta siswa mengerjakan soal perkalian } \\
\text { h. } & \text { Melakukan evaluasi }\end{array}$ \\
\hline 3 & $\begin{array}{l}\text { Pengamatan } \\
\text { (observation) }\end{array}$ & $\begin{array}{ll}\text { a. } & \text { Siswa memperhatikan proses pembelajaran } \\
\text { b. } & \text { Siswa mengerjakan soal perkalian } \\
\text { c. } & \text { Siswa bertanya kepada guru dan menyelesaian } \\
& \text { soal perkalian } \\
\text { d. } & \text { Siswa memberikan tanggapan } \\
\text { e. } & \text { Siswa menjawab soal dengan benar } \\
\text { f. } & \text { Siswa menyelesaikan soal tepat waktu } \\
\end{array}$ \\
\hline 4 & Refleksi (reflection) & $\begin{array}{l}\text { Untuk mengetahui kelebihan dan kekurangan dari } \\
\text { tindakan yang dilakukan, peneliti mengumpulkan hasil } \\
\text { observasi serta menganalisa bagaimana dengan } \\
\text { menerapkan metode Kunci ABC dapat meningkatkan } \\
\text { hasil belajar siswa pada materi perkalian. }\end{array}$ \\
\hline
\end{tabular}


Empat tahapan dalam Tabel 1 divisualisasikan dalam Gambar 1.

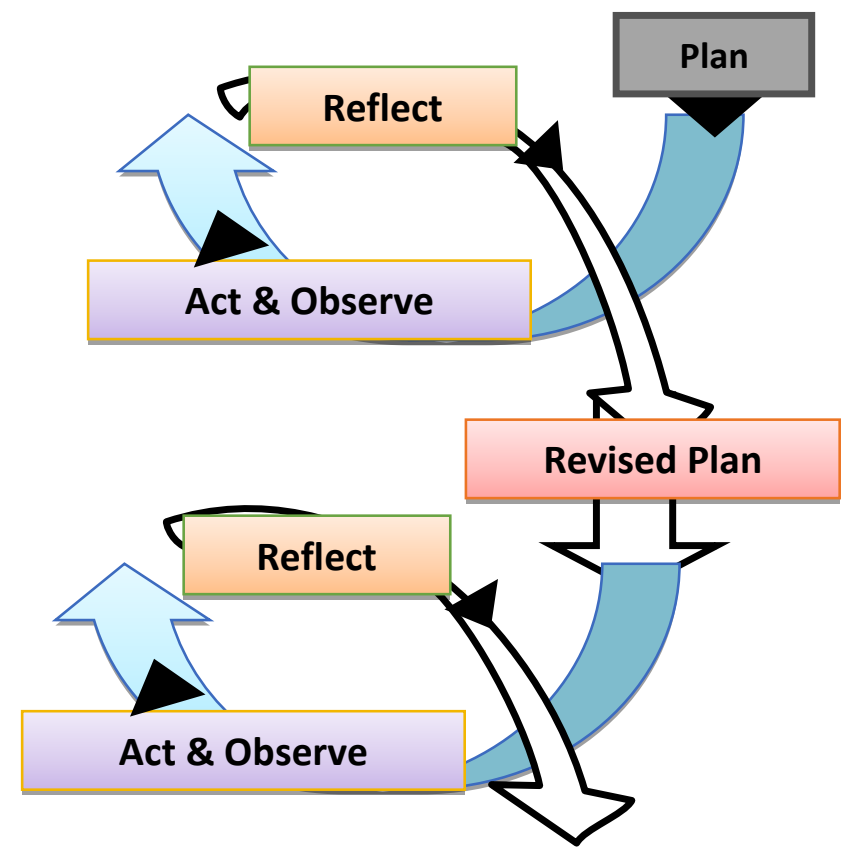

Gambar 1. Model penelitian Kemmis dan McTaggart yang dikutip oleh Taniredja (Taniredja, 2010)

\section{Siklus I: Perencanaan (Planning)}

Kegiatan yang dilakukan guru pada tahap perencanaan (planning) dalam PTK ini adalah melakukan analisis standar isi. Hal tersebut dilakukan untuk mengetahui standar kompetensi dan kompetensi dasar yang akan diajarkan kepada peserta didik. Guru kemudian memilih satu pokok bahasan yang sesuai dengan metode kunci ABC. Setelah itu, guru membuat rencana pelaksanaan pembelajaran (RPP). Selanjutnya guru membuat lembar kerja siswa. Kegiatan berikutnya, guru menyiapkan fasilitas dan sarana pendukung untuk menunjang kegiatan pembelajaran di kelas. Kemudian, guru mempersiapkan instrumen untuk merekap dan menganalisis data mengenai proses dan hasil tindakan dan diakhiri dengan menyusun alat evaluasi pembelajaran.

\section{Tindakan (Action)}

Tahap tindakan (action) yang dilaksanakan guru dalam kegiatan pembelajaran metode kunci $\mathrm{ABC}$ adalah memperkenalkan salah satu metode yang dapat digunakan untuk menyelesaikan soal perkalian. Kemudian guru menjelaskan secara khusus tentang penggunaan metode kunci $\mathrm{ABC}$ dalam 
menyelesaikan soal perkalian. Ketika menggunakan metode kunci ABC dalam menyelesaikan soal perkalian, ada beberapa langkah didemonstrasikan oleh guru ke siswa di kelas, yaitu:

1) Langkah A: Guru mengajar siswa untuk mengalikan angka puluhan dengan angka puluhan, kemudian hasil perkalian ini dikalikan 100.

2) Langkah B: Guru mengajar siswa untuk mengalikan secara silang antara puluhan dengan satuan, hasil perkalian itu kemudian ditambahkan dan dikali 10.

3) Langkah C: Guru mengajar siswa untuk mengalikan antara satuan dengan satuan, kemudian hasilnya dikalikan 1.

Gambar 2 menunjukkan visualisasi formasi metode kunci ABC dan Tabel 2 memberikan gambaran identifikasi metode kunci $\mathrm{ABC}$.

A.

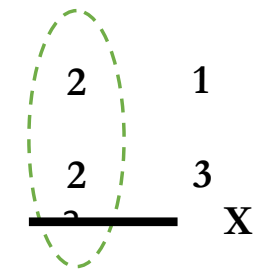

B.

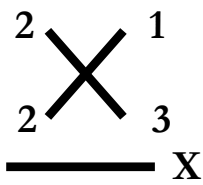

C.

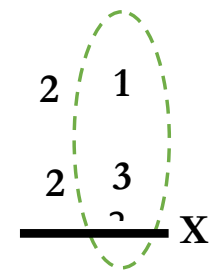

Gambar 2. Visualisasi Metode Kunci ABC

Tabel 2. Identifikasi Kunci ABC

\begin{tabular}{cccc}
\hline Kunci & Sifat & Nilai & Keterangan \\
\hline A & Perkalian (x) & Kunci & Sifat \\
B & Penjumlahan (+) & Puluhan & Hasil B x 10 \\
C & Perkalian (x) & Satuan & Hasil C x 1 \\
\hline
\end{tabular}

Setelah guru menjelaskan materi tentang perkalian dengan menggunakan metode kunci $\mathrm{ABC}$, guru memberikan soal kepada siswa terkait materi perkalian. Contoh soalnya seperti pada Gambar 3.

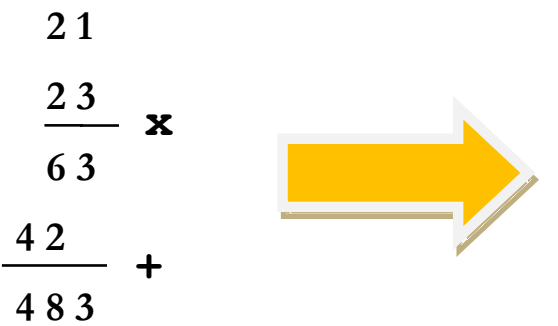

$$
\begin{array}{llr}
\mathrm{A}=2 \times 2 & =4 \longrightarrow 400 \\
\mathrm{~B}=(2 \times 3)+(1 \times 2) & =8 \longrightarrow 80 \\
\mathrm{C}=1 \times 3 & =3 \longrightarrow 3 \\
\hline \text { Hasil ABC } & = & 483
\end{array}
$$

Gambar 3. Contoh Soal Matematika dengan Metode Kunci ABC 
Langkah selanjutnya adalah guru menjelaskan kepada siswa cara mengerjakan soal perkalian dengan menggunakan metode kunci ABC. Selanjutnya, guru membimbing siswa dalam mengerjakan soal-soal perkalian yang diberikan. Setelah itu, guru meminta siswa untuk mengerjakan soal perkalian yang telah diberikan. Langkah terakhir adalah guru melakukan evaluasi berupa penilaian terhadap hasil kerja siswa dalam menyelesaikan soal perkalian dengan menggunakan metode kunci ABC.

\section{Pengamatan (Observation)}

Berdasarkan hasil pengamatan yang peneliti lakukan pada saat proses pembelajaran berlangsung, siswa menyimak dan memperhatikan dengan seksama penjelasan guru tentang bagaimana cara menggunakan metode kunci ABC. Selain itu, ketika siswa diminta mengerjakan soal perkalian, semua siswa mengerjakannya dengan aktif. Mayoritas siswa dapat mengerjakan soal perkalian dengan benar dan selesai tepat waktu sesuai dengan batas waktu yang telah disepakati antara guru dan siswa. Namun, masih ada sebagian siswa yang kurang memahami materi perkalian dan cara penyelesaiannya dengan menggunakan metode kunci $\mathrm{ABC}$.

\section{Refleksi (Reflection)}

Hasil refleksi atas siklus pertama penelitian ini yang dilakukan selama tiga kali pertemuan adalah bahwa hasil tes belajar siswa pada setiap pertemuan tersebut masih berada di bawah KKM yang diinginkan. Ketuntasan individual 65 dan ketuntasan klasikal 75\%. Kendati belum tuntas, hasil belajar siswa tetap mengalami peningkatan pada siklus satu, baik pada pertemuan pertama, kedua, dan ketiga.

\section{Siklus II}

Pada siklus I tindakan dengan metode kunci ABC di pembelajaran matematika pada siswa kelas IV belum berhasil mencapai ketuntasan individual dan ketuntasan klasikal yang diharapkan, sehingga perlu dilanjutkan pada siklus II. Siklus II ini pelaksanaannya sama dengan siklus I dan dilakukan dengan memperbaiki kelemahan-kelemahan yang terjadi pada siklus I.

Teknik pengumpulan data dalam penelitian ini adalah menggunakan teknik pengukuran dan teknik dokumentasi. Teknik pengukuran menggunakan instrumen berupa tes tertulis. Tes tertulis yang diberikan kepada siswa berupa tes formatif (menyelesaikan soal). Sedangkan teknik dokumentasi dengan mengambil data-data dari catatan dan dokumen, seperti: data hasil belajar sebelum dilakukan siklus, foto selama proses pembelajaran dengan menerapan metode kunci $\mathrm{ABC}$, dan lembar nilai siswa. Tujuannya adalah untuk melengkapi data penelitian, misalnya untuk mengetahui jumlah 
siswa dan untuk mengetahui kemampuan siswa terhadap materi operasi perkalian.

Teknik analisis data yang digunakan dalam penelitian ini adalah teknik analisis data statistik deskriptif kualitatif. Dalam penelitian ini tujuan dari analisis statistik deskriptif kualitatif adalah untuk mendeskripsikan data tentang hasil belajar matematika siswa pada materi perkalian. Data mengenai hasil belajar matematika siswa pada materi pokok perkalian dianalisis untuk mengetahui ketuntasan belajar siswa secara individual. Untuk mengetahui peningkatan hasil belajar matematika siswa dengan metode kunci $\mathrm{ABC}$ maka digunakan rumus $\mathrm{P}=\mathrm{F} / \mathrm{N} \times 100, \mathrm{P}$ (angka persentase), $\mathrm{F}$ (frekuensi yang dicari persentasenya), dan $\mathrm{N}$ (jumlah frekuensi atau banyaknya individu) (Sudijono, 2003). Pengelompokan empat kriteria penilaian digunakan untuk mengetahui meningkat atau tidaknya hasil belajar siswa. Apabila 81\%-100\% dikatakan sangat baik, 61\%-80\% dikatakan baik, 41\%-60\% dikatakan cukup, 21\%-40\% dikatakan kurang, dan 0\%-20\% dikatakan sangat kurang (Ridwan, 2005). Penelitian ini dikatakan berhasil apabila minimal $75 \%$ hasil belajar siswa mencapai KKM yaitu 65 pada materi perkalian. Siswa dikatakan tuntas secara individual jika hasil belajar siswa $\geq 65$, setelah penerapan metode kunci ABC.

\section{Hasil dan Pembahasan}

\subsection{Hasil Belajar Siswa sebelum Diberi Tindakan}

Hasil analisis terhadap studi awal pada kelas tempat PTK ini berlangsung diperoleh dari guru matematika yang mengajar di kelas IV (lihat Tabel 3).

Tabel 3. Nilai Hasil Ulangan Siswa sebelum Diberi Tindakan

\begin{tabular}{|c|c|c|c|c|c|}
\hline \multirow{2}{*}{ No } & \multicolumn{2}{|c|}{ Tuntas } & \multicolumn{2}{|c|}{ Tidak Tuntas } & \multirow{2}{*}{ Keterangan } \\
\hline & $\mathrm{F}$ & $\%$ & $\mathrm{~F}$ & $\%$ & \\
\hline 1 & 8 & $42 \%$ & 11 & $58 \%$ & Rata-rata nilai 52,4 \\
\hline
\end{tabular}

Tabel 3 menunjukkan bahwa dari 19 siswa kelas IV di sekolah tersebut, hanya 8 atau $42 \%$ siswa yang tuntas dan memperoleh nilai di atas KKM. Sedangkan sisanya, 11 atau 58\% siswa, tidak tuntas karena memperoleh nilai di bawah KKM. Nilai KKM yang telah ditetapkan adalah 65 , sementara rata-rata nilai hasil ulangan hanya 52,4. Begitu pula dengan persentase ketuntasan hasil belajar, masih berada di bawah KKM yang telah ditentukan sebesar 75\%. Mencermati paparan data yang masih rendah tersebut, guru dan peneliti merasa perlu adanya upaya peningkatan hasil belajar yang lebih serius. Salah satu alternatif yang ditawarkan dalam PTK ini adalah dengan menggunakan metode kunci ABC. 


\subsection{Hasil Belajar Siswa setelah Tindakan}

Untuk melihat perkembangan hasil belajar siswa setelah dilakukan tindakan dapat diamati melalui pengerjaan soal latihan tertulis pada siklus I dan siklus II.

\section{Data Siklus I}

Pada siklus I dilakukan 3 kali pertemuan dan 3 kali latihan dan diperoleh hasil latihan sebagaimana tertera di dalam Tabel 4.

Tabel 4. Persentase Hasil Latihan Siswa pada Siklus I

\begin{tabular}{|c|c|c|c|c|c|}
\hline \multirow{2}{*}{ Pertemuan } & \multicolumn{2}{|c|}{ Tuntas } & \multicolumn{2}{|c|}{ Tidak Tuntas } & \multirow{2}{*}{ Rata-rata Nilai } \\
\hline & $\mathrm{F}$ & $\%$ & $\mathrm{~F}$ & $\%$ & \\
\hline I & 8 & $50 \%$ & 8 & $50 \%$ & 56 \\
\hline II & 13 & $68 \%$ & 6 & $32 \%$ & 57 \\
\hline III & 13 & $72 \%$ & 5 & $28 \%$ & 59 \\
\hline
\end{tabular}

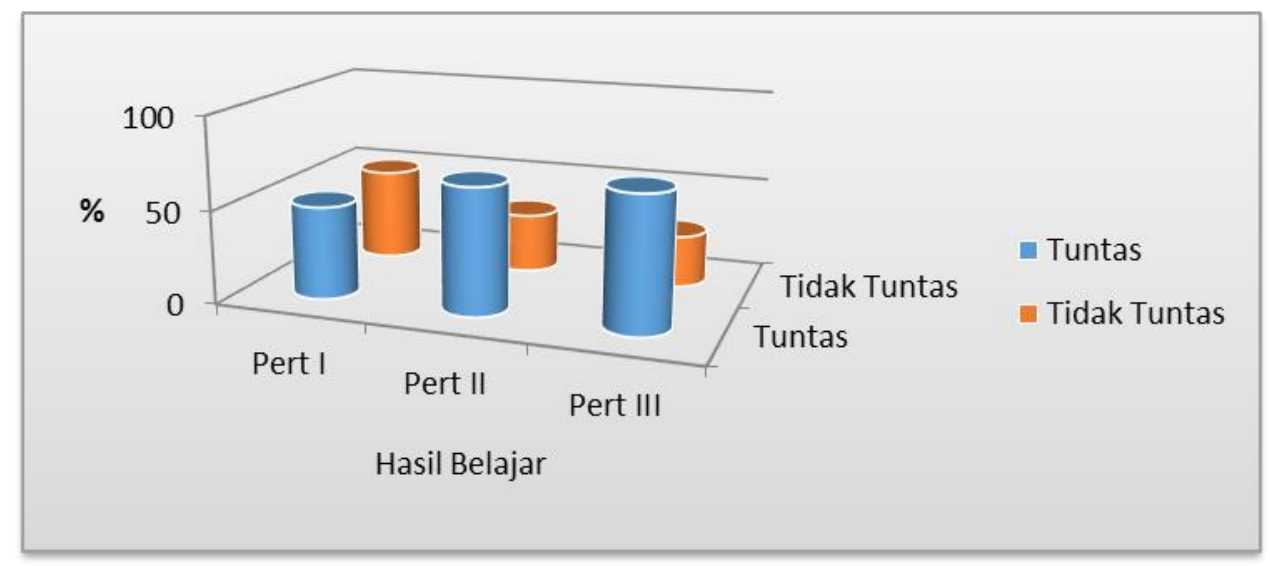

Gambar 4. Persentase Hasil Latihan Siswa pada Siklus I

\section{Refleksi Siklus I}

Pada siklus ini, hasil latihan siswa mengalami peningkatan kendati masih berada di bawah nilai KKM yang diharapkan 65 untuk ketuntasan individual dan 75\% secara klasikal. Tabel 4 menunjukkan hasil belajar siswa pada siklus ini dengan rincian: 1) pada pertemuan I nilai ketuntasannya hanya $50 \%$ secara klasikal, dengan nilai rata-rata $56 ; 2$ ) pada pertemuan II mencapai ketuntasan $63 \%$ secara klasikal, dengan nilai rata-rata 57;3) pada pertemuan III mencapai ketuntasan sebesar $72 \%$ secara klasikal, dengan nilai rata-rata 59. Secara umum, hasil belajar siswa belum mencapai KKM yang 
diinginkan. Hal tersebut dapat dilihat dari hasil ulangan harian pada siklus I, dari 19 orang siswa, hanya 14 orang $(74 \%)$ yang memperoleh nilai di atas KKM 65. Sedangkan sisanya 5 orang (26\%) masih di bawah KKM yang telah ditetapkan.

Pada siklus I, guru menghadapi beberapa kendala dalam menerapkan metode kunci ABC. Pertama, guru kesulitan dalam hal manajemen waktu. Masalah ini muncul karena siswa belum terbiasa menggunakan metode kunci $\mathrm{ABC}$ dalam menyelesaikan soal perkalian. Kedua, guru kurang mengawasi siswa dalam mengerjakan latihan, sehingga masih ada siswa yang melihat teks perkalian saat mengerjakan latihan. Ketiga, guru kurang memperhatikan manajemen kelas, sehingga masih ada siswa yang menganggu temannya saat mengerjakan latihan. Berbagai kendala ini diupayakan untuk diminimalisir pada siklus II.

\section{Analisa Data Hasil Belajar Siklus I}

Data tentang hasil belajar siswa setelah siklus I dilaksanakan diperoleh dengan mengadakan tes tertulis yang diikuti 19 orang siswa dengan jumlah 5 soal berbentuk essay. Jenis tes ini digunakan untuk mengetahui tingkat penguasaan siswa terhadap materi yang telah dipelajari selama siklus I. Hasil analisa data secara ringkas dapat dilihat pada Tabel 5.

Tabel 5. Persentase Siswa Tuntas dan Tidak Tuntas pada Siklus I

\begin{tabular}{llllll}
\hline \multirow{2}{*}{ No } & Tuntas & \multicolumn{3}{l}{ Tidak Tuntas } & \multirow{2}{*}{ Keterangan } \\
& $\mathrm{F}$ & $\%$ & $\mathrm{~F}$ & $\%$ & Rata-rata Nilai 62 \\
\hline 1 & 14 & $74 \%$ & 5 & $26 \%$ & \\
\hline
\end{tabular}

Tabel 5 menunjukkan bahwa dari 19 orang siswa yang diteliti, 14 orang (74\%) sudah memperoleh nilai sama atau di atas KKM yaitu 65, sisanya 5 orang (26\%) masih memperoleh nilai di bawah KKM. Persentase siswa yang sudah tuntas belajar secara klasikal masih di bawah KKM yang telah ditetapkan, yaitu sebesar $75 \%$.

Sebelum tindakan dilaksanakan, salah satu permasalahan yang ditemui di kelas ini adalah rendahnya hasil belajar siswa. Dari hasil ulangan harian I dan II diketahui bahwa rata-rata hasil belajar siswa masih di bawah KKM yang telah ditetapkan. Setelah tindakan pada siklus I dilaksanakan, nilai ratarata siswa meningkat menjadi 62 , dengan persentase siswa yang tuntas belajar mencapai $74 \%$. Peningkatan nilai rata-rata siswa ini karena secara berangsur-angsur siswa mulai terbiasa menggunakan metode kunci $\mathrm{ABC}$ dalam menyelesaikan operasi perkalian. Metode ini memudahkan mereka untuk memecahkan setiap soal-soal dengan lebih cepat dan benar. Kondisi ini diharapkan mampu memberikan dampak posisif pada peningkatan hasil belajar. 


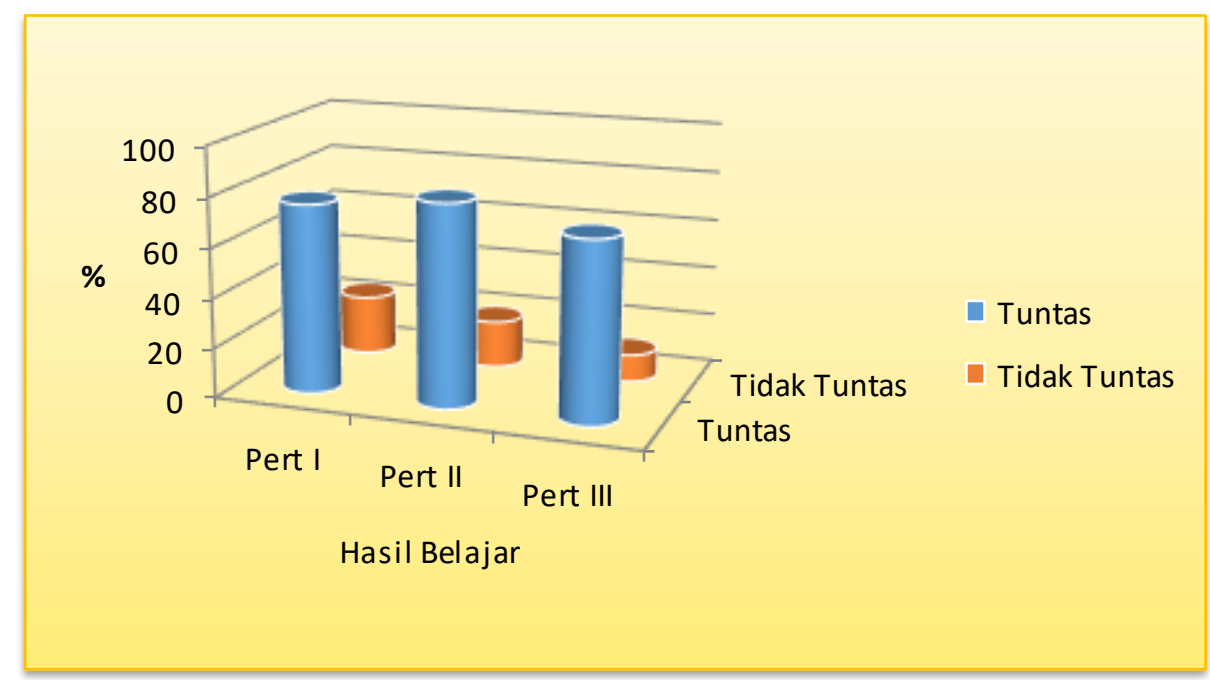

Gambar 5. Persentase Hasil Latihan Siswa pada Siklus II

Indikator keberhasilan peningkatan hasil belajar yang ditetapkan pada penelitian ini yaitu $75 \%$. Siswa yang memperoleh nilai tuntas belajar belum mencapai angka tersebut. Dengan demikian, dapat dikatakan bahwa tindakan yang dilakukan pada siklus I belum mampu menyelesaikan permasalahan di kelas yang diteliti. Oleh sebab itu, perlu dilakukan tindakan lanjutan dengan memperbaiki hal yang masih belum berjalan optimal sebagaimana mestinya.

\section{Data Siklus II}

Tindakan pada siklus II diadakan sebanyak 3 kali pertemuan dan 3 latihan dengan masih melakukan tahapan-tahapan seperti yang diterapkan pada siklus I sambil melakukan perbaikan-perbaikan yang menjadi kendala sebagaimana yang dipaparkan pada refleksi siklus I. Data hasil latihan siswa dapat dilihat pada Tabel 6.

Tabel 6. Persentase Hasil Latihan Siswa pada Siklus II

\begin{tabular}{|c|c|c|c|c|c|}
\hline \multirow{2}{*}{ Pertemuan } & \multicolumn{2}{|c|}{ Tuntas } & \multicolumn{2}{|c|}{ Tidak Tuntas } & \multirow{2}{*}{ Rata-rata Nilai } \\
\hline & $\mathrm{F}$ & $\%$ & $\mathrm{~F}$ & $\%$ & \\
\hline I & 13 & $76 \%$ & 4 & $24 \%$ & 65 \\
\hline II & 13 & $81 \%$ & 3 & $19 \%$ & 67 \\
\hline III & 16 & $89 \%$ & 2 & $11 \%$ & 75 \\
\hline
\end{tabular}

\section{Refleksi Siklus II}

Dari data hasil tes tertulis yang dikumpulkan pada siklus ini, hasil latihan siswa mengalami peningkatan, baik pada pertemuan I, II, maupun III. 
Jika dibandingkan dengan hasil belajar sebelumnya (lihat Tabel 4), hasil belajar siswa pada siklus II di pertemuan I mencapai nilai ketuntasan $76 \%$ secara klasikal dengan nilai rata-rata 65 . Hasil belajar siswa pada pertemuan II mencapai ketuntasan 88\% secara klasikal dengan nilai rata-rata 73, dan pada pertemuan III mencapai ketuntasan sebesar $89 \%$ secara klasikal dengan nilai nirai rata-rata 75 . Berdasarkan hasil ulangan harian pada siklus II, dari 19 orang siswa terdapat 17 orang siswa (89\%) yang sudah memperoleh nilai di atas KKM 65, sedangkan sisanya hanya 2 orang siswa (11\%) yang memperoleh nilai di bawah KKM. Karena hasil belajar siswa pada siklus II sudah mencapai KKM yang diinginkan, maka PTK ini dicukupkan sampai pada siklus II ini saja dan tidak lagi dilanjutkan ke siklus berikutnya.

\section{Analisa Data Hasil Belajar Siklus II}

Data tentang hasil belajar siswa setelah siklus II dilaksanakan diperoleh dengan mengadakan tes tertulis yang diikuti 19 orang siswa dengan jumlah 5 soal berbentuk essay. Jenis tes ini digunakan untuk mengetahui tingkat penguasaan siswa terhadap materi yang telah dipelajari dan dan melihat hasil belajar selama Siklus II. Hasil analisa data hasil belajar siswa pada Siklus II dalap dilihat pada Tabel 7.

Tabel 7. Persentase Siswa Tuntas dan Tidak Tuntas pada Siklus II

\begin{tabular}{llllll}
\hline \multirow{2}{*}{ No } & Tuntas & \multicolumn{4}{c}{ Tidak Tuntas } \\
& $\mathbf{F}$ & $\mathbf{\%}$ & $\mathbf{F}$ & $\mathbf{\%}$ & Keterangan \\
\hline 1 & 17 & $89 \%$ & 2 & $11 \%$ & Rata-rata Nilai 62 \\
\hline
\end{tabular}

Dari Tabel 7 dapat dilihat bahwa dari 19 orang siswa, 17 orang siswa (89\%) sudah memperoleh nilai sama atau di atas KKM yaitu 65, sisanya 2 orang siswa (11\%) memperoleh nilai di bawah KKM. Persentase siswa yang sudah tuntas belajar secara klasikal sudah di atas standar KKM yang telah ditetapkan yaitu 75\%. Persentase siswa yang memperoleh nilai sama atau di atas KKM mengalami kenaikan sebesar 19 dan nilai rata-rata siswa meningkat dari 62 pada siklus I menjadi 81 pada siklus II. Hasil belajar yang diperoleh pada siklus II terjadi karena adanya peningkatan aktivitas siswa, baik dalam proses pembelajaran maupun selama menegerjakan soal-soal latihan. Siswa sudah mulai terbiasa menyelesaikan soal-soal perkalian dengan menggunakan langkah-langkah metode kunci ABC. Metode ini memudahkan mereka untuk menyelesaikan setiap soal-soal dalam perkalian dengan lebih cepat dan benar.

Sesuai dengan indikator keberhasilan peningkatan hasil belajar yang telah ditetapkan pada penelitian ini, yaitu minimal $75 \%$ siswa sudah mencapai ketuntasan belajar maka dapat dikatakan bahwa tindakan yang 
dilaksanakan pada siklus II sudah dapat menyelesaikan permasalahan di kelas yang diteliti.

\section{Analisa Perkembangan Hasil Belajar dari Siklus I ke Siklus II}

Berdasarkan hasil tes tertulis yang telah dilaksanakan oleh siswa dalam proses pembelajaran selama dua siklus diperoleh hasil belajar siswa rata-rata pada Siklus I 62\%. Maka perlu diadakannya siklus berikutnya, yaitu Siklus II, karena hasil yang diperoleh pada Siklus I masih di bawah persentase yang diharapkan yaitu $75 \%$.

Setelah dilaksanakan siklus II diperoleh hasil belajar siswa dengan rata-rata $81 \%$. Fakta ini menunjukkan bahwa adanya peningkatan hasil belajar yang diperoleh siswa. Dengan demikian indikator persentase yang telah ditetapkan sebesar $75 \%$ telah tercapai. Untuk lebih jelasnya perkembangan itu dapat dilihat pada Gambar 6.

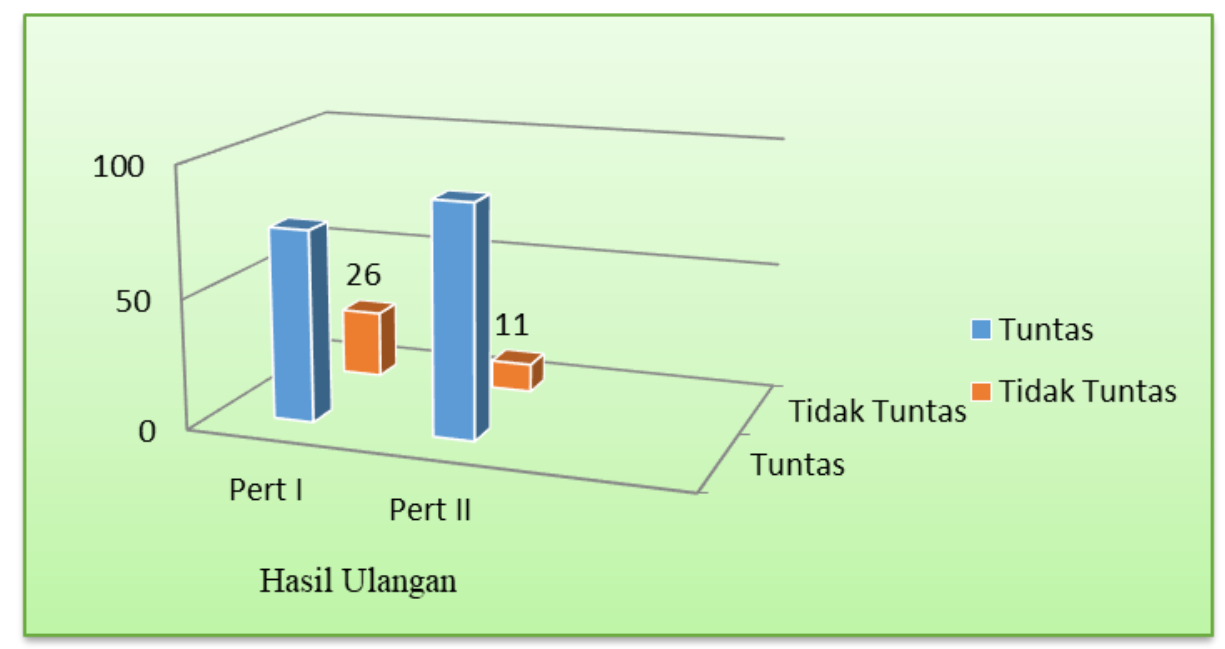

Gambar 6. Persentase Perkembangan Hasil Ulangan Siswa Pada Siklus I dan II

Dengan memperhatikan hasil latihan yang dilakukan pada akhir proses pembelajaran dapat dilihat peningkatan hasil belajar siswa dari sebelum dilakukan tindakan, siklus I dan siklus II. Peningkatan tersebut dapat dilihat pada Tabel 8.

Tabel 8 menunjukkan peningkatan hasil belajar siswa secara umum dari sebelum tindakan ke siklus I, dan dari siklus I ke siklus II. Tabel tersebut menujukkan penurunan jumlah siswa yang bernilai rendah (dibawah 55-64) di bawah KKM yaitu pada data awal 11 orang $(57,90 \%)$ setelah siklus I tinggal 5 orang $(26,31 \%)$, dan pada siklus II hanya tersisa 2 orang $(10,52 \%)$. 
Tabel 8. Distribusi Hasil Belajar Matematika

\begin{tabular}{llllllll}
\hline \multirow{2}{*}{ NO } & \multirow{2}{*}{ Rentang Nilai } & \multicolumn{2}{l}{ Data Awal } & \multicolumn{2}{l}{ Siklus I } & \multicolumn{2}{l}{ Siklus II } \\
& & F & P & F & P & F & P \\
\hline 1 & $85-100$ & - & - & - & - & 8 & $42,1 \%$ \\
2 & $75-84$ & 2 & $10,5 \%$ & 4 & $21,1 \%$ & 4 & $21,1 \%$ \\
3 & $65-74$ & 6 & $31,6 \%$ & 10 & $52,6 \%$ & 5 & $26,3 \%$ \\
4 & Dibawah 55-64 & 11 & $57,9 \%$ & 5 & $26,3 \%$ & 2 & $10,5 \%$ \\
\multicolumn{2}{l}{ Ketuntasan kelas yang dicapai } & 8 & $42,1 \%$ & 14 & $73,7 \%$ & 17 & $89,5 \%$ \\
\hline \multicolumn{2}{l}{ KKM matematika } & 65 (Enam Puluh Lima) \\
\hline
\end{tabular}

Pada sisi yang lain, terjadi peningkatan untuk siswa yang bernilai tinggi (65 keatas) di atas KKM yaitu pada data awal hanya 8 orang $(42,10 \%)$, setelah siklus I meningkat hingga 14 orang $(73,68 \%)$ dan pada siklus II meningkat lagi menjadi 17 orang $(89,5 \%)$. Dengan demikian telah terjadi penurunan jumlah siswa yang bernilai rendah dan terjadi peningkatan pada siswa yang bernilai tinggi dari siklus I ke siklus II, maka dapat disimpulkan penelitian ini berhasil. Jadi, metode ABC dapat dipertimbangkan sebagai metode alternatif dalam mata pelajaran matematika, khususnya operasi hitungan perkalian. Kemampuan operasi perhitungan perkalian di tingkat sekolah dasar ini akan membantu siswa dalam menyelesaikan operasi aritmatika dasar pada saat mereka memasuki jenjang sekolah menengah pertama kelak (La Hadi \& Dedyerianto, 2020).

\section{Kesimpulan}

Berdasarkan pembahasan dan analisis hasil penelitian yang telah dilakukan, dapat disimpulkan bahwa penerapan metode Kunci ABC yang baik dan benar telah teruji dapat meningkatkan hasil belajar siswa kelas IV di sebuah sekolah dasar negeri di Provinsi Riau, Indonesia. Peningkatan hasil belajar siswa ini dapat dilihat pada nilai rata-rata sebelum tindakan, nilai rata-rata siklus I, dan nilai rata-rata siklus II. Tingkat keberhasilan tertinggi dalam PTK ini berada pada siklus II. Keberhasilan PTK ini karena guru telah menerapkan metode kunci ABC dengan baik sehingga mencapai persentase ketuntasan yang diharapkan. 


\section{Ucapan Terima Kasih}

Ucapan terima kasih tidak lupa kami haturkan kepada semua pihak yang telah berkontribusi dalam penelitian ini, terutama kepada kepala sekolah, guru-guru, dan siswa-siswi di sekolah dasar negeri tempat penulis melakukan penelitian.

\section{Daftar Pustaka}

Caffriyati, R. A., \& Lisa, Y. (2015). Penggunaan metode Kalkulator Jari Tangan untuk meningkatkan pemahaman operasi perkalian pada materi keliling dan luas persegi dan persegi panjang. Jurnal Pendidikan Dasar Perkhasa: Jurnal Penelitian Pendidikan Dasar, 1(1), 27-43.

Ekasanti, A. (2017). Penerapan metode Jarimatika untuk meningkatkan kemampuan berhitung perkalian bagi anak tunagrahita ringan. Jurnal Pendidikan Khusus, 9(5), 1-8.

Hendra, \& Widiastuti, A. N. (2013). Jari hitung cepat ABC. Jakarta: PT. Elex Media Komputindo.

La Hadi, A., \& Dedyerianto, D. (2020). Analisis data miskonsepsi siswa sekolah menengah pertama dalam menyelesaikan operasi aritmatika dasar. Al-Ta'dib: Jurnal Kajian Ilmu Kependidikan, 13(1), 18-33.

Olsen, J. R. (2015). Five keys for teaching mental math. The Mathematics Teacher, 108(7), 543-548. doi:10.5951/mathteacher.108.7.0543

Ridwan. (2005). Belajar mudah penelitian untuk guru, karyawan dan peneliti pemula. Bandung: Alfabeta.

Rizal, M. (2011). Proses berpikir siswa SD berkemampuan matematika tinggi dalam melakukan estimasi masalah berhitung. Dalam Prosiding Seminar Nasional Penelitian, Pendidikan, dan Penerapan MIPA, 14, 19-28.

Sari, R. P. (2011). Meningkatkan hasil belajar siswa dalam perkalian melalui penerapan metode Kunci ABC pada mata pelajaran matematika di kelas III SD Negeri 028 Rimbo Panjang Kecamatan Tambang Kabupaten Kampar. Skripsi tidak dipublikasi. Riau: Universitas Islam Negeri Sultan Syarif Kasim Riau. 
Stott, D., Hewana, D., Koliti, N., \& Mase, Y. (2013). Using dice and card games in mental maths sessions. Dalam Proceedings of the 19th Annual Congress of the Association for Mathematics Education of South Africa, 2, 61-63.

Sudijono, A. (2003). Pengantar statistik pendidikan. Jakarta: Raja Grafindo Perkasa.

Surat, I. M. (2017). Penerapan metode Kejar untuk meningkatkan kemampuan berhitung pada operasi perkalian pada pendidikan dasar. Emasains: Jurnal Edukasi Matematika dan Sains, 6(2), 194-202.

Suryadi. (2012). Penelitian tindakan kelas (PTK) dan penelitian tindakan sekolah (PTS). Surabaya: Andi.

Taniredja, T. (2010). Penelitian tindakan kelas untuk pengembangan profesi guru praktik, praktis dan mudah. Bandung: Alfabeta.

Verschaffel, L., Luwel, K., Torbeyns, J., \& Van Dooren, W. (2009). Conceptualizing, investigating, and enhancing adaptive expertise in elementary mathematics education. European Journal of Psychology of Education, 24(3), 335-359. 